\title{
CONTROLLED CHAOS STRATEGY AND INSTRUMENTS FOR ITS REALIZATION IN SERBIA: COMMUNICATION AND PSYCHOLOGICAL ASPECT ${ }^{2}$
}

https://doi.org/10.18485/iipe_balkans_rssc.2020.ch15

Abstract: The author deals with the communication procedures and psychological mechanisms used in hybrid wars and color revolutions and their potential application in the Republic of Serbia. In the first part of the paper, the focus is on the vague relation between the terms 'hybrid war' and 'color revolution' with the term 'controlled chaos'. The author takes the latter term as the broadest framework within which to consider the activities of hybrid war and color revolutions, deemed to be instruments for the controlled chaos strategy realization. The second part of the paper discusses the basic communication procedures and psychological mechanisms underlying them, which are used for information and psychological management of societies and gives examples of their application in specific societies. In the last part of the paper, the author explains why contemporary Serbian society is suitable for the realization of controlled chaos. The author argues that its most pronounced weakness is the national and state identity crisis and the associated 'idea of the future' and points out measures that could be taken to develop the state's 'immunity' to potential controlled chaos activities.

Keywords: controlled chaos, hybrid war, color revolution, Serbia.

\section{INTRODUCTION}

Armed combat and gun-related violence, which resulted in enormous human and economic losses, have been, until recently, a fundamental way

\footnotetext{
${ }^{1}$ Associate Professor, Faculty of Political Science, University of Belgrade, Serbia. E-mail: sinisa.atlagic@fpn.bg.ac.rs.

${ }^{2}$ This paper originated within the framework of a scientific project of the University of Belgrade - Faculty of Political Science, "Political identity of Serbia in the regional and global context" (record number: 179076), funded by the Ministry of Education, Science and Technological Development of the Republic of Serbia.
} 
of restructuring the world. The events of the late twentieth and early twentyfirst centuries, however, marked the transition to a new form of redistribution in the modern world. In it, unconventional forms and methods of conducting armed combat are increasingly becoming instruments of geopolitical competition, most commonly referred to as 'hybrid wars', 'color revolutions' and 'controlled chaos'. The latter gained importance after the publication of Chaos Theory and Strategic Thought text by Steven Mann, an American expert in foreign policy, in 1992, in which he stated that '...We can learn a lot if we view chaos and reorganization as opportunities, and not pursue stability as an illusory goal...' (Mann, 1992 in: Prav, 2016) and that the system needs to be brought to a state of 'political criticality'. According to Mann, given certain conditions, it (the system - S. A.) will then unavoidably enter chaos and transformation. Mann also writes that if we 'give the US advantage in communications and growing global mobility capabilities, the virus (in the sense of an ideological infection) will be self-replicating and will expand chaotically. Therefore, our national security will be preserved'. And further: 'This is the only way to establish a long-term world order. If we cannot accomplish such an ideological change in the whole world, we will have only sporadic periods of calm between catastrophic transformations' (Mann, 1992 in: Prav, 2016).

The other two terms mentioned above were sporadically used at the end of the past and the beginning of this century, and more frequently since 2010. Until then, for example, the term 'hybrid war' was not formally used in US military departments as the concepts of 'irregular war' and 'asymmetric war' (Цыганков, 2015, p.17) were considered sufficient to describe changes in the security environment. However, the point of view whose authors find it to be a completely new phenomenon that will become the war of the future (Бжезинский, 2005) has gradually crystallized. It is the first time the NATO alliance has officially referred to it in point 13 of the conclusion of the Declaration of the Alliance Summit held in Scotland in 2014. It, among other things, states a military alliance needs to prepare itself for participation in new type wars - 'hybrid wars' (Бартош, 2014 in: Грачиков, 2015, p. 137).

In the academic community, the term 'hybrid war' was first used by constructivists who tried to highlight its nature and characteristics. From their point of view, the essence of 'hybrid war' is that it is a conflict between political communities because of symbols (hypotheses, languages, identities, interests, etc.). However, before addressing the ambiguous relationship between these interrelated concepts, let us emphasize they are considered in the context of traditional and alternative approaches to the study of war 
and armed conflict. But also the causes of their public politicization present in the media and academic literature are analyzed. The topic of this paper will be discussed in the first sense.

\section{HYBRID WARS AND COLOR REVOLUTIONS - INSTRUMENTS FOR REALIZING A CONTROLLED CHAOS STRATEGY?}

Similar to the title of this chapter, but not in question form, is the title of text by V. A. Achkasov which was part of the collection 'Hybrid Wars' in the chaotic world of the 21st century published by Moscow State University (2015), probably the most extensive edition in the Russian Federation devoted to this issue (Ачкасов, 2015, pp. 242-258). It (the subtitle) expresses an almost undivided assessment of Russian authors dealing with the phenomena of the hybrid war and color revolutions that these are activities related to global politics, that is, the geopolitical rivalry of their organizers, and not revolutionary events in the narrow sense of the word or civil or war conflicts concerning unresolved issues in a political community and/or its relations with neighboring communities. They place them within the aforementioned conceptual framework of the controlled chaos theory and bind primarily to 'American idea factories' (Манойло, 2015, p. 263) such as the RAND Corporation, certain universities, NATO, etc.

In contrast, in the US and European political discourse on hybrid wars, the Russian Federation and its international activities ${ }^{3}$ take a special place. There are numerous documents discussing propaganda campaigns and the information war being waged by Russia to weaken the institutions and, in general, the ideological cohesion in the West. Thus, recently, the RAND wrote about the Russian digital war in Eastern Europe (Helmus et al., 2018), pointing indirectly to the importance of the European space for Russia in the geopolitical game. To counter these campaigns, the European Council formed the East StratCom Task Force in $2015^{4}$. Still, in the context of this chapter, devoted to the theoretical aspect of the paper, the 2017 document of the European Council for Foreign Affairs, Controlling Chaos: How Russia Manages Political War in Europe, is of importance. It summarizes that intending

\footnotetext{
${ }^{3}$ In addition to the Russian Federation, in the context of hybrid war analysis, particular attention in the West has been given to the activities of Iran, China and North Korea.

${ }^{4}$ The official website of the European Union states that the East StratCom Task Force was 'set up to address Russia's ongoing disinformation campaigns' (Questions, 2018).
} 
to weaken the EU and NATO, and to create a more conducive environment for itself, Russia uses a wide range of actors, from officials and the media, through military threats, to business lobbies and spies (Galeotti, 2017, p. 1). To create controlled chaos, according to this document, countries undertake those activities that, so coordinated, in other documents, such as the aforementioned conclusion of the 2014 NATO summit, are called hybrid wars. According to the alliance experts, these include a wide range of direct combat and covert operations that are, by a unique plan, realized by armed forces, partisan units, and other irregular formations with the participation of civilian components. These operations are closely related to propaganda campaigns, cyber-attacks, and local separatist actions. Information operations (operations and instruments of information-psychological warfare), according to A. V. Manoylo, one of Russia's most prominent contemporary scholars of the field, and the techniques of controlled chaos have been used successfully in hybrid wars and color revolutions (Манойло, 2015, p. 271).

The latter refers to the 'fine application of psychological mechanisms and communication techniques successfully masked to look like an "uncontrolled process"' (Ананченко, 2018, p. 24) since these are not 'classical' revolutions, triggered by the 'objective development of a historical process' (Манойло, 2015, p. 271). Unlike revolutions, these actions do not result in changes to the social order but are carried out with the aim of bringing about regime changes in political communities through nonviolent citizen actions. Coming to power, conditionally, of a new social group, only brings changes in the political course and a change in foreign policy priorities. The shift of political elites, however, has a limited character: power is passed from the hands of one group, which has held a dominant position in the government system, into the hands of a coalition of other, diverse segments of the elite. The results of these actions boil down to changes within the ruling elite that result from the unlawful seizure of power. The 'color revolution' is nothing more than a 'vivid metaphor that leads to delusion and hides an externally organized coup' (Ананченко, 2018, p. 24).

From this very brief overview, conditioned by the limited scope of the paper, it is clear different authors see the relationships of key concepts used in this paper differently. ${ }^{5}$ However, what they have in common are the communication procedures that make up a kind of 'connective tissue'. After

\footnotetext{
${ }^{5}$ The interpretation of the relationship of these terms is reminiscent of the interpretation of the relationship between the concept of 'propaganda' and concepts close to it such as 'political communication', 'political marketing', 'public relations', 'public diplomacy' and
} 
all, the aforementioned Mann refers to it as - 'give the US advantage in communications ....' (Mann, 1992 in: Prav, 2016). They, according to Manoylo, can be decisive in compelling an opponent to capitulate, and the combat operations of armed forces can play a service role in the sense that they supply information warfare organizers with the PR material necessary for information attacks on the consciousness and subconsciousness of the enemy by inflicting direct damage (using information weapons) or to covertly manage its consciousness and behavior (Манойло, 2015, р. 263). This paper aims to point out the basic psychological mechanisms and communication procedures that possibly could be applied to carry out the above-mentioned activities in the Western Balkans or the Republic of Serbia.

\section{Communicative procedures and psychological mechanisms applied in controlled chaos realization}

Based on the above, one could also conclude no war in history has ever happened that was not a hybrid one. In other words, there was no armed conflict that was not accompanied by intense persuasion about it, whether interpersonal communication and spreading rumors or the use of mass media. This view is grounded, but what seems to differentiate between the hybrid wars of today and the earlier armed conflicts is the intensity of persuasion that came to the fore with the development of communication technologies, primarily through the development of mass media and the internet. The difference does not seem to be in whether in the modern armed conflict, as in the previous wars, the front line is evident or not, but rather a pronounced combination of soft force (persuasion) and hard force (use of physical force). In short, modern wars are hybridized by the use of modern means of communication. Do we have a better example than the combination of political persuasion and armed combat on a daily basis in the event of NATO attacks on Serbia in 1999, when strong propaganda activity that had been waged against Serbs in the former Yugoslavia for a decade or so was 'supplemented' by bombing military and civilian targets from the air, only to be followed by the overthrow of power holders by civil protests? ${ }^{6}$ Or the even

the like (Slavujević, 2009; Атлагић, 2011), which are also closely related to the topic of this paper. Terminological harmonization does not seem to be over since the term 'hybrid chaos war' has started to be used recently.

${ }^{6}$ For more details on the propaganda preparation of NATO military activities against Serbia during 1998, see Radojković, 2018. 
more plastic example of the events in Kiev during the protests at the Maidan when the sniper fire kindled the aggression of the mass gathered in a civilian protest against the authorities, which in itself makes up the material for pronounced persuasion carried out through the mass media and the internet.

Political persuasion aims to make the person to whom the message is addressed to behave following the intentions of the one who sends the message. The aim, therefore, is not to stay at the level of attitudinal gaining of the individual, but to ensure his or her support in terms of doing or not doing. To do this, it is necessary to activate the appropriate psychological mechanisms of the individual through communication. In other words, for people to take to the streets and create a mass, they would need to develop a stimulus, a motive for some behavior. And it develops when people have some unrealized expectations. In the so-called young democracies and political systems of the non-western type, the stereotype of a corrupt official who uses his position in the system of government to enrich himself at the expense of other members of society is often constructed. Deception and theft are distinguished as a feature characteristic of all members of the group, most often during election campaigns when the image of a corrupt official is transferred to a political party or movement to which he belongs. A stereotype is formed by which the process of information processing is then managed. It is basically a psychological mechanism of simplifying the image of the world based on which the propaganda figure of the enemy develops, which, in a milder form, takes the form of finding the culprit. The effectiveness of the mechanism described above is particularly enhanced by the informal style of communication through the Internet. The message structure, quick access to information and emotionally charged images are attracting an increasing number of users, giving the political process a new emotional backdrop and transforming it into an entertaining performance. From this point of view, the behavior of social network users is reminiscent of crowd behavior. The starting point for this comparison is anonymity as a characteristic of the process of communicating on social networks. Why is an individual in the crowd willing to undertake activities he would individually turn away from? The anonymity of a man in the crowd releases him of responsibility for the results of the action.

The basic psychological mechanism that activates in the crowd is the socalled emotional contagion. Researchers of contemporary color revolutions point out that rhythm is what enhances this mechanism. Thus, unless the goal of the protest organizer is to encourage the crowd to engage in some kind of aggressive action, its aim remains to bring people to a certain 
emotional state using rhythm when the individual ceases to control the information that enters his consciousness. He or she does not analyze them rationally, and the so-called mechanism of suggestion can be applied then. But if the intention is to turn the crowd into an aggressive crowd, then it is necessary, first, to bring the emotional state to a level where the individual cannot control himself and when he develops the need to express his emotions in the form of action. The only thing left is for the individual to be suggested what to do (Ананченко, 2018, p. 50).

In initiating destructive political behavior in the realization of controlled chaos, it is common to use another propaganda figure - the so-called sacral sacrifice figure. It is especially suitable for crowd management. The purpose of its use is not only to catalyze the protest mood but also to personalize the responsibilities of the 'first man', the leader of the regime. That is why it is important in controlled chaos realization to establish a public associative link between the leader or the political system itself and its sacrifice. In this way, information and psychological narrowing of responsibility are achieved - from the political order as a whole to its leader, which is necessary for enhancing the mobilization potential of protests and accelerating society polarization. This, again, opens the space for attribution as a psychological mechanism - the leader and the system are no longer just corrupt but also criminal. From this follows the political order leader dehumanization and the willingness to take radical actions against him. This, in terms of communication, ends with slogans such as those known - 'Antichrist died on Christmas' dedicated to the execution of N. Ceau $\square$ escu on December 25, 1989, 'Sloba Saddam', 'Yanukovych - our Gaddafi', etc.

Applying the sacral sacrifice propaganda figure is today current in protest activities in Hong Kong. There, the slogan 'Reclaim Hong Kong, revolution of our times' also pays tribute to Edward Leung, who used this slogan in his election campaign and is currently serving a six-year prison sentence for rioting and assaulting a police officer during the so-called Fishball Revolution of 2016. Though not physically present at the demonstrations, Leung has become a kind of spiritual leader for protesters, offering guidance and inspiration from behind bars (Hui, 2019). He becomes a celebrity fabricated by the work of specialists in the so-called fame game, and as such, serves for impression management in the political sphere through his image. In the same way, Nelson Mandela was used by the media to awaken people's sympathy in the activities of the anti-apartheid movement in South Africa. As in the case of Edward Leung, Mandela did not play the role of compassion manager. He was given the media role of 
an absent performer. The role was designed and played instead of him by anti-apartheid movement activists (Lou, 2013, p. 157). In Hong Kong, Leung's role is played by activists of the movement against Hong Kong's reintegration into China.

Sacral sacrifice is one of several basic psychological and communication mechanisms undertaken to manage the space of meaning and symbols to realize the controlled chaos strategy. One of them is the transformation of mass perceptions of social and political reality. This is basically about a gradual reframing - a change in the coordinate system through which social and political processes are perceived (Ананченко, 2018, p. 54). Thus, in Serbia, the state and national question, which dominated the political and electoral offer in the first half of the 1990s and which represented the pledge of future prosperity, was replaced by social issues and the country's accession to the EU as an instrumental value, that is, a way of achieving terminal value - a better life (Slavujević and Atlagić, 2015). The story of the relative backwardness of the country has been replaced by the story of its absolute backwardness compared to the advanced world. This is accompanied by polarization not only at the level of ideological and political views and views of daily social issues but also at the level of moralizing motives. The representatives of the governing structures are presented primarily as fraudsters and thieves, at various levels - from frauds they commit at the economic level to vote-stealing. It follows that it is the moral obligation of every honest man, regardless of his or her own views on the world of politics, to oppose immoral and criminal authority. In such circumstances, when polarization on the 'we-they' line becomes crucial in political discourse, the possibility of reaching an agreement at the level of sense is zero. Any attempt to cooperate with the government becomes synonymous with betraying the 'revolutionary ideals' of its opponents.

In the self-identification of 'our' as opposed to 'their' in the physical and virtual space of protest activities, performance culture plays an important role (Ананченко, 2018, p. 54). In addition, it has the function of psychoemotional mobilization, but its entertaining role is to release the demonstration participants of feelings of fear and a sense of responsibility, to translate the protest activity into a form of play, to highlight the nonviolent character of the action and thus to attract what as many supporters as possible. So, for example, in Serbia in 2000, protests against the then authorities had a pronounced musical form.

Particularly noteworthy in the context of this analysis is the psychological character of activities that fall under the 'controlled chaos' and 
are related to the crisis of the national and state identity and, in correlation with it, 'ideas about the future'. Namely, most countries in which political lives of the last two decades activities that fall under 'color revolutions' or 'hybrid war' could be identified are basically divided societies that, at the time these activities took place, lacked an effective consolidation model of national identity. The dividing lines in these societies are deep ethnoreligious, socio-cultural, territorial-tribal... The internal conflict in these societies is the basis for carrying out the aforementioned activities, the results of which cannot be reduced only to regime change. Delegitimization of power and regime crisis is, in most cases, an introduction to the systemic collapse of state institutions that can result in the loss of state territory or state dissolution.

\section{Vulnerabilities of contemporary Serbia and its ability to counteract chaos}

The aforementioned crisis of the national and state identity and the associated 'idea of the future' are undoubtedly the greatest weaknesses of contemporary Serbia. Among the unresolved issues, it has been facing since the breakup of Yugoslavia that make it a 'fertile ground' for the realization of the controlled chaos idea, the most serious is the ethnic-cultural one. Different ethnic and cultural segments of present-day Serbia - on the one hand, Orthodox Serbian and on the other, primarily Muslim - Albanian and Bosnian - are in such positions that they do not intend to make concessions for one another. The majority Orthodox Serbian segment was not able to impose their identity attitudes, symbolism, and meaning on their opponents for a longer period to ensure their ethnic-cultural model the status of general national identity. This became more than clear, first by the refusal of the majority Muslim population in Bosnia and Herzegovina to stay in truncated Yugoslavia, and then by the secession of Kosovo and Montenegro's exit from the state union with Serbia. Serbia simply did not have an 'unconditional veto' that could take on an integrative role in critical situations. However, at the moment, it is not without integration potential in the Western Balkans (Лобанов, 2017, p. 223) and it lies primarily in the activities of the Serbian Orthodox Church, which is an institutional platform for the symbolic integration of the Serbian national space. Consequently, the attempt to limit its operations, as in the case of the adoption of a legal solution in Montenegro declaring its property state-owned, can be viewed, among other things, as a new fight in the modern hybrid Balkan war. This is one of the indicators that could show the preparation of activities for the 
potential realization of controlled chaos in Serbia. In addition, there are illegitimate sanctions, trade embargo, financial and economic restrictions, setting up barriers to the operations of local companies in the region, barriers to free movement of citizens and capital flow, forming lists of officials and citizens of Serbia with restricted movement in neighboring countries, etc. as additional indicators. These measures have recently been implemented through Kosovo, but also Croatia. Such measures aim to slow down the pace of country development and lower the standard of living and to exert pressure on the government or to initiate changes in government by forming a broad protest movement. Establishment of instability centers near borders that would endanger its national security (as in the case of a possible threat to the constitutional position of the Republic of Srpska within Bosnia and Herzegovina or in the case of migrant crisis escalation) and deepening tensions along ethnic division lines (especially in southern Serbia and the Raška region) can also be indicators of preparation for the realization of controlled chaos in Serbia.

In societies where there is no clear 'identity policy' at the state level, the 'idea of the future' in the minds of citizens is also vague. A kind of multiplication of the identity crisis is at work - the amorphousness of national and state attitudes and symbols in the mass consciousness has been 'supplemented' by the absence of a national consolidation strategy on the part of authorities. In these conditions, the implementers of controlled chaos introduce into the mass consciousness their own utterly simplified symbols and meaning. The vacuum of national identity is supplemented by the construction of a 'first-hand idea of the future'. In the Serbian case, it is identified primarily in 'European values'. Combining the aforementioned psychological mechanisms, a multiplicative effect that enables the informational and psychological management of society is achieved.

How, in the case of contemporary Serbia, to counter these tendencies? Doing this by identifying indicators pointing to the preparation of a 'controlled chaos' realization, like the ones mentioned above, and acting prophylactically, is not enough. It is necessary to establish a complex system of political, economic, legal, informational, psychological, pedagogical and organizational measures that will develop state 'immunity' and act preventively. What this system should be based on is the formulation of a clear Serbian position in cultural policy and international relations (Копривица, 2018, p. 440). Lack of it today seems to be most easily seen in the gap between proclaimed military neutrality and Serbia's foreign policy orientation to join the European Union as part of the informal trade empire 
- Pax Americana, with NATO being its defense mechanism. Until this broad intellectual platform is formed, we can speak of overcoming the state and national identity crisis at the level of popularization of the value of belonging to the Serbian people and its tradition, which will be internally implemented through the school system and the mass media, that is, the products of mass culture. When it comes to the region, in areas where it is not possible to do it this way or through the operation of the Serbian Orthodox Church, the role should be taken on by non-governmental organizations and funds of a wide range of activities, which will, directly and indirectly, exert informational propaganda influence on the population of neighboring countries to promote the importance of Serbia and the Serbian people. From the point of view of managing the space of meaning and symbols, it is the same activity of formatting mass ideas of social and political reality in Serbia, that is, establishing a coordinate system through which it will be perceived. 'Technically,' use of a particular psychological mechanism in communication will be identical to that used or being used at the expense of Serbia. Economic growth is the key condition to realize this. In the spirit of the old maxim 'Winning is the best propaganda', economic successes can quickly boost propaganda activity to counter the information challenges from a range of controlled chaos measures.

\section{REFERENCES}

Ананченко, А. Б. (2018). Что надо знать о изетных революииях [What yоu need to know about color revolutions], Moscow, MPSU.

Атлагић, С. (2011). Политичка пропаганда: Различита схватања појма и функције [Political propaganda: Different understandings of concept and function], Политичка ревија [Political Review], 30(4), pp. 491-510.

Ачкасов, В. А. (2015). 'Гибридные войны' как инструмент реализации стратегии 'управляемого хаоса' ['Hybrid wars' as a tool for implementing the 'controlled chaos' strategy], in: П. А. Цыганков (Ed.),'Гибридные войны' b хаотозирующемся мире XXI века ['Hybrid Wars' in the chaotic world of the 21st century] (pp. 242-258), Moscow, MSU Press.

Бжезинский, 3. (2005). Выбор. Мировое господство или глобальное лидерство [The choice. Global domination or global leadership]. Moscow, International Relations.

Цыганков, П. А. (2015). [Введение] [Introduction]. In П. А. Цыганков (Ed.), 'Гибридные войны' 8 хаотозирующемся мире XXI Века ['Hybrid Wars' in the chaotic world of the 21st century] (pp. 5-28). Moscow, MSU Press. 
Galeotti, M. (2017). Controlling Chaos: How Russia Manages Political War in Europe. London, European Council on Foreign Relations.

Грачиков, Е. Н. (2015). Эксперты Израиля, США и России о 'гибридных войнах' [Israeli, US and Russian experts on 'hybrid wars'], in: П. A. Цыганков (Ed.), 'Гибридные войны' в хаотозирующемся мире XXI века ['Hybrid Wars' in the chaotic world of the 21st century] (pp. 124-142). Moscow, MSU Press.

Helmus, T. C., Bodine-Baron, E., Radin, A., Magnuson, M., Mendelsohn, J., Marcellino, W., Bega, A. \& Winkelman, Z. (2018). Russian Social Media Influence. Understanding Russian Propaganda in Eastern Europe. Santa Monica, RAND Corporation.

Hui, M. (2019, September 2). A guide to the most important chants of Hong Kong's protests, retrieved from https:/ qz.com/1699119/chants-andslogans-of-hong-kongs-protests-explained/. Accessed 23 December 2019.

Копривица, Ч. (2018). Српски пуm [Serbian Way]. Belgrade, Catena Mundi.

Лобанов, К. (2017). Западные Балканы и Сербия в ракурсе геополитического анализа современной ситуации в регионе [Western Balkans and Serbia From the Perspective of Geopolitical Analysis of the Present Situation in the Region], Godišnjak FPN [Yearbook of the Faculty of Political Science], XI(18), pp. 209-225.

Lou, E. (2013). Mediji i politički proces [The Media and Political Process]. Belgrade, Faculty of Political Science.

Манойло, А. В. (2015). Технологии 'цветных револуций' в современных проявлениях 'гибридных войн' ['Color Revolutions' Technologies in Contemporary Manifestations of 'Hybrid Wars'], in: П. А. Цыганков (Ed.),'Гибридные войны' 6 хаотозирующемся мире XXI века ['Hybrid Wars' in the chaotic world of the 21st century] (pp. 259-271). Moscow, MSU Press.

Prav, V. (2016, March 24). 'Controlled Chaos' as an Instrument of Geopolitical Warfare and 'Color Revolutions', retrieved from https:// www.globalresearch.ca/controlled-chaos-as-a-instrument-ofgeopolitical-warfare-and-color-revolutions/5516279. Accessed on 9 December 2019.

Questions and Answers about the East StratCom Task Force. (2018, December 5), retrieved from https:// eeas.europa.eu/headquarters/ headquarters-homepage/2116/-questions-and-answers-about-the-eaststratcom-task-force_en. Accessed 17 December 2019. 
Radojković, M. (2018). Uloga mas-medija u ostvarivanju ciljeva političkog marketinga [The Role of the Mass Media in Achieving Political Marketing Goals], Belgrade, Faculty of Economics.

Slavujević, Z. (2009). Političko komuniciranje, politička propaganda, politički marketing [Political Communication, Political Propaganda, Political Marketing], Belgrade, Grafocard.

Slavujević, Z. \& Atlagić, S. (2015). Vreme neispunjenih obećanja: Teme u izbornim kampanjama u Srbiji 1990-2014 [A time of unfulfilled promises: Issues in Election Campaigns in Serbia 1990-2014], Belgrade, IP Dobar naslov. 